\title{
DRESSED FOR SUCCESS? GENDERED APPEARANCE DISCRIMINATION IN THE WORKPLACE
}

\author{
Catherine Harwood*
}

Gender is a nebulous concept, linked to one's self-identity and social acceptance. Gender expression in a heterosexist society is consequently governed by particular social norms and is susceptible to prejudice. It is critical that gender is not a source of permissible discrimination in a central social space, the workplace. Current responses from the law can be ineffective due to the nature of the complaints process and the theory underlying decision-makers' reasoning. The United States has considerable gender discrimination jurisprudence and is a valuable source of options for law reform. This paper argues that statute and case law in New Zealand should expressly prohibit both inter and intra-gender discrimination. Processes should also be tightened up to avoid claims falling through the cracks in tribunal jurisdictions. Rights are hollow unless they have a real-life impact. While formal recognition does not mean the end to this particularly insidious form of discrimination, it is an important means to shift societal norms. This could generate greater equality in real terms for New Zealanders.

\section{INTRODUCTION}

Should an employer be able to compel workers to wear clothes to work? Such a requirement is widely accepted. Yet should women employees be required to wear mini skirts, or men prevented from doing so? This paper shall examine the place of gender in workplace appearance requirements. The concept of "gender" will be explored as an identity able to be shaped through employment dress codes and expectations. The legal process and discrimination law in New Zealand will be examined with reference to the jurisprudential journey of the United States, which in part has come to acknowledge the existence of inter and intra-gender discrimination. In the final parts of the paper, possible directions or solutions to New Zealand's approach to gendered appearance discrimination will be explored.

* Submitted as part of the LLB(Hons) programme at Victoria University of Wellington. 


\section{GENDER AS A PERFORMATIVE IDENTITY}

Simone De Beauvior famously stated "one is not born, but rather, becomes a woman." ${ }^{1}$ While sex is a biological categorisation, gender has been termed "social sex": the outward display of sexual biology, orientation and characteristics. These include visual cues such as a manner of walking, dress, gestures and bodily positioning. Gender messages are continuously sent and received in everyday life. Such messages build up a "normative stereotype" of gender. Scholar Anthony Appiah defined this as a social consensus on how one should "behave in order to conform appropriately to the norms associated with membership in their group."2

The structure of gender in western culture is often considered a relational binary of male to female. However, debate surrounds such gender classification. Academic and transgender attorney Dylan Vade challenged this view, instead proposing a non-linear three-dimensional arrangement. Vade considered that a "gender galaxy" included more complex identities such as transgendered persons who were attracted to either males, females or both, without having to be plotted somewhere between male and female polarities. ${ }^{3}$ Vade also challenged the notion that gender is "merely" cultural, and declared this understanding as harmful for the transgender community: ${ }^{4}$

If we see sex as biology and gender as a social construct, then we give sex more import and make it more real...then transgender people's self-identification, which is different from assignment at birth, is necessarily seen as less real.

Vade stated that biological sex classifications and sexual orientation may not align, even in those who transition from one sex to the other. ${ }^{5}$ This means that gender identity may not completely match either classification or orientation; it may only partially explain a person's gender. It is important to view gender as a real identity as perceived by the individual, not a lifestyle choice or an optional affiliation.

It has been suggested, conversely, by other social theorists such as Judith Butler that gender is not a natural trait but a learned presentation; "it is real only to the extent that it is performed." ${ }^{6}$ Such

1 Simone De Beauvior The Second Sex (trans H M Parsley, Vintage, New York, 1974) 38 (emphasis added).

2 K Anthony Appiah "Stereotypes and the Shaping of Identity" (2000) 88 Cal L Rev 41, 48.

3 Dylan Vade "Expanding Gender and Expanding the Law: Toward a Social and Legal Conceptualization of Gender that is More Inclusive of Transgender People" 11 (2005) Mich J Gender \& L 253, 261.

4 Ibid, 262.

5 "Some transgender people are straight; others are gay, some are bisexual, and some are queer. As soon as we recognise that there are more than two genders, the terms 'heterosexual' and 'homosexual' no longer make sense." See ibid, 270.

6 Judith Butler "Performative Acts and Gender Constitution: An Essay in Phenomenology and Feminist Theory" in Katie Conboy, Nadia Medina and Sarah Stanbury (eds) Writing on the Body: Female Embodiment and Feminist Theory (Colombia University Press, New York, 1997) 401, 411. 
acts, while discrete, are repeated to create the appearance of a unified and cohesive identity. They are displayed to and interpreted by the social world to create a social body. The kinds of gender acts performed are important. They must fit within defined boundaries and be accomplished in order to avoid social penalty. ${ }^{7}$ Butler's notion of an "accomplished" gender has a layer of meanings, including the appearance of a complete and cohesive identity, but also one which is performed correctly. ${ }^{8}$ There is a certain amount of flexibility to gender performances and acts can change meaning over time. ${ }^{9}$ However "it is not what is done or how it is done but who does it" 10 that determines the social value of the gender performance. Gender is tied to sex; acts must align with the biological sex of the performer. ${ }^{11}$

One way to reconcile these competing views of gender is to separate gender expression and identity. The latter indicates personal gender affiliation, while the former relates to external portrayal. An issue for some transgender persons is the reconciliation of the two. For those who fit comfortably within the biological binary, the challenge involves contesting the kinds of performances that are deemed suitable for their gender acts.

\section{GENDER IN THE WORKPLACE}

A person's appearance is important in employment. Studies have shown that attractive people are more successful at obtaining employment than their less attractive counterparts. ${ }^{12}$ Further, it has been found that attractive individuals enjoy greater employment opportunities. ${ }^{13}$ A basic part of attractiveness is the presentation of a coherent and accomplished gender. Thus, a person who performs their gender well and demonstrates attributes admired in a man or woman has an advantage.

$7 \quad$ Ibid, 412

8 Ibid.

9 A simple example of this is the acceptability of women wearing trousers.

10 Moira Gatens "A Critique of the Sex/Gender Distinction" in Moira Gatens (ed) Imaginary Bodies: Ethics, Power and Corporeality (Routledge, London, 1996) 3, 15.

11 "It is not masculinity per se that is valorized in our culture but the masculine male." Ibid, 14. This is expanded upon by Lynn Jamieson: "Because of the ranking of conventional masculinity above that of conventional femininity, to be a tomboy is a lesser offence for a girl than to be a sissy is for a boy." Lynn Jamieson "Sex and Intimacy" in Lynn Jamieson Intimacy: Personal Relationships in Modern Societies (Blackwell, Oxford, 1998) 106, 120.

12 Student Note "Facial Discrimination: Extending Handicap Law to Employment Discrimination on the Basis of Physical Appearance" (1987) 100 Harv L Rev 2035, 2039 and Karen Zakrzewski "The Prevalence of 'Look'ism in Hiring Decision: How Federal Law Should be Amended to Prevent Appearance Discrimination in the Workplace" (2005) 7 U Pa J Lab \& Emp L 431, 432.

13 Elizabeth M Adamitis "Appearance Matters: A Proposal to Prohibit Appearance Discrimination in Employment" (2000) 75 Wash L Rev 195, 196-198. 
Both women and men are judged on appearance. However it is a more powerful factor affecting employment opportunities and status for those who do not comply with the dominant masculine norm; this includes both women and men who are considered to have an inferior masculine gender. ${ }^{14}$ It has been suggested by feminist theorists that, generally, women are tied more closely to the corporeal realm than men. ${ }^{15}$ What this means for employment, then, is that women are more likely to be judged based on their appearance. Naomi Wolf in her book The Beauty Myth observed that: ${ }^{16}$

To pretend that since men have appearance standards it means that genders are treated equally is to ignore the fact that in hiring and promotion, men's and women's appearances are judged differently, and

... the beauty myth reaches far beyond dress codes into another realm.

Yet those who do not meet either masculine or feminine norms face further obstacles: firstly, inferiority in the traditional gender hierarchy and secondly as an "other" who does not perform either gender "adequately".

There may also be a difference in positions where an explicit dress code operates and one where there are instead subtle demonstrations of proper behaviour with social sanction for nonconformity. Official dress codes are usually drafted carefully to avoid gender stereotyping. While it gives the employee a good form of evidence if discriminatory requirements are in force, it also means the employer can require strict compliance. This kind of policy often operates in workplaces that have set unisex uniforms, giving little capacity to the employee to express their gender.

In workplaces without dress codes, expectations of correct attire are often linked to acknowledgement of "commercial reality". For example, CRS Recruit, an engineering recruitment consultancy, advised potential interviewees that: ${ }^{17}$

We all know that discrimination is illegal, but at the end of the day, the way that you present yourself will make a statement about who you are. ... Our advice to you would be to remember that whilst presentation seems insignificant, it can positively or adversely affect your career.

The Auckland District Law Society recommends in their publication "The Young Practitioner's Handbook" that: 18

14 This can include men who are gay, have a disability or exhibit a more feminine gender.

15 Maree Burns "Eating like an Ox: Femininity and Dualistic Constructions of Bulimia and Anorexia" (2004) 14 Feminism and Psychology 269, 274.

16 Naomi Wolf The Beauty Myth (Chatto \& Windus, London, 1990) 48.

17 CRS Recruiting "Guidelines for Interviewees" www.crsrecruit.co.nz (accessed 17 July 2006).

18 Auckland District Law Society "The Young Practitioner's Handbook" www.adls.org.nz (accessed 17 July 2006). 
As a general rule, bear in mind that you are a professional, and how you appear to the client will subconsciously affect their perception of your ability, and your firm's integrity. Never forget that law is an inherently conservative profession.

Employees are advised to decide on appropriate work attire based on "common understandings", implicitly upholding a conservative norm for appearance without risk to the employer. Expectations include gender-specific requirements, such as males wearing a shirt and tie in professional situations. While there is arguably no equivalent dominant expectation for women in professional roles, there are a myriad of other more subtle appearance requirements that can be enforced by informal social sanctions. For example, in a report by the Australian Law Reform Commission, it was found that many women in law firms felt forced to conform to masculine-defined codes of conduct, effectively excluding them from equal participation with men. ${ }^{19}$ This included firms adopting "unwritten 'feminine' dress codes."20 Further, females who were lesbian reported conforming to heterosexual feminine appearance norms to hide their sexuality and gender association out of fear of harassment and stereotyping. Heterosexist conceptions of feminine attire have pervaded workplaces, differentiating not only general female appearance from male, but also the kinds of female appearance which are acceptable.

Sex and gender hierarchies and consequent discrimination are realities in New Zealand. The Human Rights Commission's Annual Report for 2004 cited that the most significant structural discrimination was suffered by "disabled people; non-Pakeha New Zealanders in some situations; women, in some areas; and gays, lesbians, transgender and intersex people." ${ }^{21}$ In the 2005 Annual Report, employment discrimination constituted 39.5 percent of all complaints by area, by far the largest site of discrimination. ${ }^{22}$ Complaints pertaining to sex, sexual orientation or sexual harassment by ground of discrimination made up 19 percent. ${ }^{23}$ A significant proportion of complaints therefore involve employment and sex discrimination. While details of specific claims are kept confidential, the areas and grounds will interrelate. It is those who fall on the lower levels of the gender hierarchy - subordinate femininities and masculinities, transgender persons and gays and lesbians - who require the most protection in employment.

19 Australian Law Reform Commission Equality Before the Law: Women's Equality (ALRC No 69 Part II, Canberra, 2004) para 9.21.

20 Ibid, Confidential Submission 176, para 9.21.

21 Human Rights Commission Report of the Human Rights Commission and the Office of Human Rights Proceedings for the Year Ended June 2004 (Human Rights Commission, Wellington, 2004) 5.

22 Human Rights Commission Report of the Human Rights Commission and the Office of Human Rights Proceedings for the Year Ended June 2005 (Human Rights Commission, Wellington, 2005) 11.

23 Ibid, 10. 
Employees who are otherwise competent should have protection from this kind of prejudice. Discrimination law can provide such safeguards; however formal rights are hollow unless they have an impact when applied to employment realities. New Zealand's approach will be examined to assess whether such laws have been successful in practice. The approach taken by the New Zealand authorities will be compared with those in the United States, as developments in the law should, in the author's view, follow its lead.

\section{NEW ZEALAND'S APPROACH TO DISCRIMINATION}

In New Zealand, human rights are governed by statute, but unlike the United States they are not entrenched in supreme law. ${ }^{24}$ There is a tiered system for employment discrimination complaints, including both arbitration-type bodies and the formal Court process. There are advantages and weaknesses of such a system, which will be explored by looking to the process itself and the claims that have gone through it. Because our quasi-judicial bodies are not required to provide the same level of intensity of legal reasoning as the courts, the possible principles behind the decisions will be exposed by reference to United States case law.

\section{A Legislative Provisions}

Discrimination law in New Zealand is primarily governed by the Human Rights Act 1993. Section 21 of the Human Rights Act sets out a list of prohibited grounds of direct discrimination, including sex and sexual orientation. ${ }^{25}$ The Human Rights Act specifies that indirect discrimination is also unlawful. A requirement which is prima facie neutral but which in practice has the effect of excluding or imposing a disadvantage on a person on one of the prohibited grounds in section 21 is illegal. ${ }^{26}$ These grounds of discrimination are prohibited in employment as a covered activity in

24 The relevant provisions for the legislation governing employment discrimination is Title VII of the Civil Rights Act 1964 (US). The relevant sections are as follows:

$\S$ 703(a) It shall be an unlawful employment practice for an employer--

(1) to fail or refuse to hire or to discharge any individual, or otherwise to discriminate against any individual with respect to his compensation, terms, conditions, or privileges of employment, because of such individual's race, color, religion, sex, or national origin........

$\S 703(e)(1)$ Notwithstanding any other provision of this title it shall not be an unlawful employment practice for an employer to hire and employ employees ...where religion, sex, or national origin is a bona fide occupational qualification reasonably necessary to the normal operation of that particular business or enterprise.

Debate as to whether this impacts on public awareness of rights or the amount of claims which arise is outside the scope of this paper. However it is conceivable that the lack of entrenched constitutional emphasis could affect the way New Zealanders view human rights law.

25 Human Rights Act 1993, s 21(1)(a).

26 Human Rights Act 1993, s 65. 
section 22 of the Act. The Employment Relations Act 2000 declares that employers may not discriminate when hiring, dismissing or retiring employees on a direct or indirect basis of the prohibited grounds of section 21 of the Human Rights Act. ${ }^{27}$ This is a significant change from the now repealed Employment Contracts Act 1991, which excluded some of the prohibited grounds of discrimination which were included in the Human Rights Act. Sexual orientation, while a prohibited ground under the Human Rights Act, was not part of the Employment Contracts Act. The repeal of this Act and its replacement by the Employment Relations Act has widened the legislative protection from discrimination in employment.

\section{B Legal Processes}

While the discrimination legislation is relatively comprehensive, its application has been conflicting. It is a commercial reality that problems stemming from employment matters are often resolved internally. There is a multi-layer process for employment discrimination claims, with quasi-judicial bodies responsible for settling low-level claims that are not able to be resolved within the workplace. An employee can either lodge a complaint with the Human Rights Commission (the HRC) or a personal grievance with the Employment Relations Authority (the ERA). ${ }^{28}$ Proceedings in these forums can be kept confidential, meaning that there is limited information available to the public regarding the kinds of decisions and principles that arise from claims. Importantly, an employee can only pursue one avenue of redress. If no desirable outcome can be reached here, the complaint may be taken to the Employment Court, provided strict criteria for appeal are met.

Proceedings of the Employment Court are complicated and the Ministry of Justice strongly advises that a lawyer should represent parties. ${ }^{29}$ Determinations of fact are restricted to the Employment Court. This is an important responsibility as discrimination can be a matter of degree rather than a particular type of employment requirement. The opportunity to appeal is only granted by allowance from the Court of Appeal on points of law and if the claim is in the greater public interest. This makes the Employment Court the final avenue for most claims. The issue of practical access to justice is therefore pertinent. The Employment Court is not a realistic forum in which to find a solution for many claimants, particularly as many cases of discrimination arise in low-paid occupations and costs may be prohibitive.

The ERA as the practical "end of the line" is concerning as there can be a large gap between the claimant's legal rights and the outcome of the case. An example of this is the 1996 case of Trilford $v$ Car Haulaways $\operatorname{Ltd}^{30}$ where a female applicant was not considered for a vacant position which the

27 Employment Relations Act 2000, ss 104 and 105.

28 See, for example "Taking a Personal Grievance: Choice of Procedure" www.ers.govt.nz (accessed 19 July 2006).

29 Ministry of Justice "Employment Court" www.justice.govt.nz (accessed 17 July 2006).

30

Trilford v Car Haulaways Ltd [1996] 2 ERNZ 351. 
employer's branch manager had described to her as being "more male orientated". ${ }^{31}$ The Employment Court held that Mrs Trilford was the victim of sex discrimination and observed in obiter dicta that this extended to indirect gender discrimination. ${ }^{32}$ The Court also described the Employment Tribunal, as the body was before the Employment Relations Act came into force, as giving "little thoughtful attention"33 to the facts, thereby deciding the case wrongly. While inaccuracies do occur, they should not be so acute as to warrant such reprimand from the Court. Such mistakes are concerning because of the reliance placed on the body to resolve disputes definitively.

\section{The Overlap of Jurisdiction}

With only one avenue of redress allowed, it is important for claimants to choose the tribunal most likely to result in a fair outcome. However, both bodies have shown reluctance to address issues of gendered appearance discrimination, meaning that a sense of justice may not be achieved whichever path is chosen.

In one case, a woman brought a complaint to the HRC because she had been required by her employer to wear a dress to work. ${ }^{34}$ The HRC decided that: ${ }^{35}$

[I]n the past, it had not taken up complaints concerning dress and appearance, considering this issue to be a question of industrial relations. To be consistent, the Commission decided not to investigate the complaint further pursuant to s 35(1) of the Human Rights Commission Act 1977.

The HRC refused to consider her claims surrounding appearance, citing grounds of consistency as the reason for refusing to exercise their statutory power to investigate. It is curious that consistency was the main reason for refraining to address the complaint since the body does not in its nature adhere to a system of precedent. Consistency is valued above practical justice, while it should really come after it.

In the ERA case of Montaperto $v$ Midcentral District Health Board, ${ }^{36}$ an employer gave an employee warnings for contravening several requirements, including an "ongoing unprofessional dress code ... with inappropriate exposure of your midriff, as well as failure to tie back your long

31 Ibid, 359 Palmer J.

32 Ibid, 356 Palmer J.

33 Ibid, 366 Palmer J.

34 (Parties unnamed) (19 December 1990) Human Rights Commission Hosking File C253/89.

35 Ibid.

36 Montaperto $v$ Midcentral District Health Board (2 April 2004) Employment Relations Authority Wellington WA 38/04. 
hair, and long polished fingernails while on duty." 37 The ERA found that the employee did have a personal grievance for loss of dignity and humiliation, but did not award any compensation. In Parore $v$ Sheldon Hammond (Pty) Ltd, ${ }^{38}$ a competent older woman was denied employment because the employer wanted to hire a younger, prettier woman for the position. The ERA, while sympathetic to the claimant, considered its hands tied: ${ }^{39}$

Although I do not think Ms Parore was treated fairly in relation to that prospective employment, I do not have the jurisdiction to order remedies for distress arising out of any kind of discrimination or breach where an employment agreement has yet to be entered into. The circumstances here are such that they are more likely to give rise to a cause of action under the Human Rights Act than under the Employment

Relations Act. I can do nothing more to assist Ms Parore with her problem.

This statement from the ERA is clearly at odds with the legislative scope given to it under the governing Act, where it is able to inquire into hiring decisions. Such inaccuracies may be greater under a quasi-judicial system due to the absence of trained legal professionals in the role of decision-maker and the lack of legal advice provided to claimants. The referral of the claim in Parore as more suited to the Human Rights Act is impotent considering that the claimant was unable to resubmit her claim to the HRC.

Because there is no system of precedent in these forums, the bodies can make such claims without reference to similar cases or principles which have been established and tested. This means that outcomes can be uncertain and subject to the personal judgement of those in the ERA rather than a body of law. While this gives "practical justice" a place in deciding claims, decisions may be contrary to principles and legal analysis developed in the courts. Further, statements from the HRC show that they hold consistency above practical justice to such a high degree that there is a refusal to investigate important parts of a complaint. What this means for claimants is that there is a watertight escape route for the bodies; they can either cite consistency (applying some kind of precedent not to look into such matters) or practical justice (protecting the status quo) to silence the claim.

It appears that both bodies also avoid investigating gendered employment discrimination claims by stating they are more suited to the others' expertise or field. The HRC avoids discussing gendered appearance matters in employment on the basis that it is an industrial relations issue, while the ERA refuses because it belongs in the domain of human rights. This effectively means that both tribunals are silent on the issue and there is no guarantee that claims of this nature will be satisfactorily addressed in these forums.

37 Ibid, para 13.

38 Parore v Sheldon Hammond (Pty) Ltd (23 November 2001) Employment Relations Authority Auckland AA 196/01 [Parore].

39 Ibid. 
The overlapping jurisdictions and the large amount of discretion given to the forums are troubling. They can refuse to address the complaint out of jurisdictional suitability, precedent or the application of practical "justice" giving no relief to otherwise valid claims. This will end the process for claimants unless employees wish, and have the means to, embark on an expensive appeal to the Employment Court.

\section{Jurisprudence}

A recent example of ERA and Employment Court reasoning is the case of Williams $v$ Kimberley Fashions Ltd. ${ }^{40}$ Melissa Williams was fired from her job as an assistant manager at clothing store Kimberleys. At the ERA hearing, the body upheld the actions of the senior staff member who fired Williams for refusing to wear make-up. The claimant stated that foundation reacted badly with her skin and that she objected to the wearing of makeup; "it was a human rights issue and this was no longer the 1950s and women could choose." ${ }^{41}$ However the ERA found that: 42

There is nothing unreasonable in a fashion retailer wanting its staff to look good, and that must include, within reason, the requirement to wear makeup. This requirement does not breach the relationship of trust and confidence nor is it contrary to an employee's human rights.

In this instance, the ERA justified the employer's requirements by stating that staff should "look good"; it refused to acknowledge the impositions placed on the primarily female staff. The limitation of "within reason" was not explained or qualified by any kind of comparative requirements for male staff. There is nothing except a personal opinion which distinguishes success of the claim from failure.

On appeal to the Employment Court, the decision was reversed and the claim succeeded. ${ }^{43}$ Judge Perkins held that requiring the complainant to wear makeup was unlawful, but restrained the reach of the decision by refusing to comment on whether that constituted sexual discrimination. Instead, the learned Judge reasoned that: ${ }^{44}$

I prefer to deal with these issues simply on a contractual basis. There was no contractual requirement that Ms Williams wear facial makeup. There was no basis for Kimberleys to demand that she did. The breach of duty constituted by this and the other matters mentioned led to her resignation.

40 Williams v Kimberley Fashions Ltd (8 August 2005) Employment Relations Authority Auckland AA 300/05 [Williams].

41 Ibid.

42 Ibid, 39.

43 Williams v Kimberley Fashions (12 December 2006) Emp Ct AK AC 72/06.

44 Ibid, para 48 Judge Perkins. 
While the complainant was successful in her appeal, gaining $\$ 30,000$ in compensation, the judgment may actually be a blow to discrimination jurisprudence, as the reasoning continued: 45

Having said that, there must be an entitlement for an employer to insist on standards of dress, cleanliness and tidiness for employees in a retail clothing shop. The problem for the employer in this case is that there was no evidence that the employee had breached those standards. To deal with the issue more specifically as discrimination or breach of wider rights issues ... is fraught with difficulties. There may well be workplaces where the nature of the work requires facial makeup. One obvious example could be a women's cosmetic retail shop. There may be others. It is not beyond argument that an employer in a women's clothing boutique could require staff to wear facial makeup so long as it was a mutual, contractual requirement.

The decision avoided answering the thorny questions posed by Williams' counsel, with the Judge declining to treat it as a test case for discrimination. The silence on the issue leaves the employer confident that so long as requirements are fairly "reasonable" (conventional) and contained in a contract, they are enforceable.

The comments from the ERA and to a lesser degree the Employment Court are strikingly similar to the historical treatment of discrimination claims in United States. In St Cross v Playboy Club of New York, ${ }^{46}$ Playboy won its case using a Bona Fide Occupational Qualification (BFOQ). ${ }^{47}$ The statutory justification of the BFOQ can only be utilised if the employer can demonstrate the necessity of the criterion in employment, ${ }^{48}$ which is similar to the caveat that the New Zealand authorities have read into discrimination claims. In a BFOQ, the burden of proof rests on the employer and if not satisfied, justifies the imposition of liability. The defendant company argued that because sexual entertainment was its primary service, hiring attractive females was required. ${ }^{49}$

The inclusion of customer preferences and market justifications is concerning in such a strong caveat to employee rights. Unlike physical necessities of employees, such factors are qualitative and are able to be manipulated according to employers' purposes. Using a BFOQ justification can enable employers to impose discriminatory requirements. The reasoning of the ERA and the Employment Court in Williams similarly contains implicit acknowledgment that the status quo should not be disturbed.

45 Ibid, para 49 Judge Perkins.

46 St Cross v Playboy Club of New York (1971) Appeal No 773 Human Rights App Bd Case No CFS 22618-70 NY.

47 See above $\mathrm{n} 24$ for the full section 703(e)(1) of the Civil Rights Act.

48 Dothard v Rawlinson (1977) 433 US 321, 332-337 Stewart J.

49 St Cross v Playboy Club of New York, above n 46, 341. 
Historical United States jurisprudence is reflected in current New Zealand case law. Employers have been entitled to uphold different standards for men and women. While reasons for this have not been expounded often in decisions of the HRC or ERA, it is likely that "customer preferences" and a willingness to preserve the status quo lies behind them. This means that the binary gender norm is still upheld, and there is discrimination against those who do not fall within it. The presence of the Court in employment discrimination suits means that a settled body of law can be established, creating coherence and consistency between cases. However, there are few appeals from the ERA or HRC; it will take many cases to build a comprehensive body of precedent.

\section{E Affirmation of Protection of Gender in Current Law}

While the Human Rights Act does offer reasonable protection, it has been unclear whether individuals who do not fit within traditional gender norms, such as transgender persons, are covered by the provisions. Member of Parliament Georgina Beyer attempted to introduce a Member's Bill inserting gender into the list of prohibited grounds in 2004. ${ }^{50}$ The Bill was created to clarify and define the scope of the existing provisions of the Human Rights Act in order to evaluate whether further protections were required, ${ }^{51}$ and was designed to protect transgender and intersex people. ${ }^{52}$

The Bill was withdrawn from the ballot in August 2006 after Acting Solicitor-General, Cheryl Gwyn, issued an opinion affirming that transgender persons were protected by clauses which prohibited sex discrimination. 53 "Sexual orientation" was considered to be unlikely to give relief as unfair treatment falling under this ground ought to stay tied to sexual preference rather than gender display. ${ }^{54}$ It was considered important to retain the separation of these categories. Cases were examined from courts in Canada, Europe, the United Kingdom and the United States, which held that gender was protected within "sex" provisions. The opinion resolved "...it is unnecessary to amend the Human Rights Act in order to ensure protection from discrimination on grounds of gender identity in New Zealand. Those decisions will be influential on New Zealand courts." 55

50 Human Rights (Gender Identity) Amendment Bill (2004 No 225-1).

51 I am indebted to Georgina Beyer for elucidating this point. Interview with Georgina Beyer MP (the author, Wellington, 27 June 2006).

52 The definition of "gender identity" in the Bill was "the identification by a person with a gender that is different from the birth gender of that person, or the gender assigned to that person at birth, and may include persons who call themselves transsexual, transvestite, transgender, cross-dresser, or other description." Human Rights (Gender Identity) Amendment Bill, above n 50, cl 21(1)(n).

53 "You have asked whether prohibition of discrimination on grounds of gender identity is already provided for in the Human Rights Act. In my view, it is." Crown Law Office "Opinion on Human Rights (Gender Identity) Amendment Bill" (Crown Law Office, Wellington, 2006) para 2.

54 Ibid, para 27.

55 Ibid, para 30. 
What is unclear, however, is the way the New Zealand courts will interpret the concept of discrimination. The case of Quilter $v$ Attorney-General highlights the legwork yet to be done in New Zealand on this matter. ${ }^{56}$ This case was brought by three lesbian couples who claimed that the reading of the Marriage Act as excluding same sex couples - and therefore denying such couples the right to marry - was discriminatory and breached section 19 of the Bill of Rights Act $1990 .{ }^{57}$ Gault and Keith JJ held that the inquiry into discrimination lay in there being unequal treatment between persons in comparable circumstances; there was no discrimination if every person was subject to the same restrictions. Conversely, Tipping and Thomas JJ considered that unequal impact could also be discriminatory. The difference in these perspectives can be viewed with reference to the United States cases of Jespersen $v$ Harrah's Operating Co Inc ${ }^{58}$ and Frank $v$ United Airlines Inc. ${ }^{59}$

In the case of Jespersen, the plaintiff was fired for refusing to wear makeup at work. Her employer, Harrah's, introduced a set of "Personal Best" appearance standards that employees were required to meet in order to be seen as performing competently. Women were required to wear makeup, nail polish, stockings and have their hair styled or teased, while men only had requirements to not wear makeup or nail polish and be clean shaven. Jespersen argued that this constituted sex discrimination because the requirements created a burdensome expense that only women had to absorb. Jespersen also argued that the requirements for female staff cost more in money and time, and perpetuated sex-role stereotypes that subordinated women to men. ${ }^{60}$ The Court rejected these arguments, holding that requiring different standards did not illegally discriminate on the basis of sex. ${ }^{61}$ Essentially, if both men and women were subject to the same level of restrictions, they were not being treated differently and so there was no discrimination.

This meant that for gendered appearance requirements to be discriminatory, they had to amount to difference in treatment, with pointers such as being more expensive to undertake or resulting in

56 Quilter v Attorney-General [1998] 1 NZLR 523 (CA).

57 New Zealand Bill of Rights Act, s 19 reads: Freedom from discrimination:

(1) Everyone has the right to freedom from discrimination on the grounds of discrimination in the Human Rights Act 1993.

(2) Measures taken in good faith for the purpose of assisting or advancing persons or groups of persons disadvantaged because of discrimination that is unlawful by virtue of Part 2 of the Human Rights Act 1993 do not constitute discrimination.

58 Jespersen v Harrah's Operating Co Inc (2006) 444 F 3d 1104 (9th Cir).

59 Frank $v$ United Airlines Inc (2000) 216 F 3d 845 (9th Cir).

60 Sherry F Colb "Makeup Requirements for Female Employees Violate Anti-Discrimination Law: Why a Federal Appeals Court Erred in Ruling to the Contrary" (11 January 2005) www.findlaw.com (accessed 24 April 2006)

61 Jespersen, above n 58, 1108 Shroeder CJ. 
obvious sexual objectification, in a comparison between men and women. ${ }^{62}$ Commentator Sherry Colb noted that: 63

Because women do not all look alike, the presumption that they all should be wearing each of these kinds of makeup carries with it the implication that there is a particular way that women - all women are supposed to look. ... To deny women a choice in the matter permits no escape from the sex object role that was once required in the service professions.

Thus the test formulated in this case can defend employment requirements even if they uphold normative gender and sex-role stereotypes. ${ }^{64}$ It overlooks the purpose of discrimination laws, which is to make sex discrimination prima facie unlawful.

Conversely, the Californian case of Frank $v$ United Airlines Inc ${ }^{65}$ acknowledged the possibility of indirect discrimination, or unequal impact within the "unequal burdens" analysis. ${ }^{66}$ The Court upheld claims of sex discrimination of women who were subject to different standards of weight requirements than their male co-workers. Plaintiff Leslie Frank, an employee, claimed that this inconsistency was discriminatory because maximum weight limits for men corresponded to large male body frames, but such limits for women were medium female body frames. Judge Fletcher described direct discrimination, or disparate treatment, as when an employer "treats some people less favorably than others because of their sex." ${ }^{67}$ In contrast, disparate impact arises when an employer's practice is "facially neutral but ... in fact fall[s] more harshly on one group than another." 68 Frank was found to have been discriminated against due to the disparate impact of the weight restrictions. ${ }^{69}$ However the Court distinguished the case from situations where both sexes faced equal appearance regulations, holding that "[a]n appearance standard that imposes different but essentially equal burdens on men and women is not disparate treatment." ${ }^{70}$ This has the effect of

62 Ibid, 1110 Shroeder CJ.

63 Colb, above n 60.

64 It is important to emphasise that the inquiry into undue impact, because limited to quantifiable measures, is unlikely to uncover and thus protect against normative inequalities.

65 Frank, above n 59.

66 Ibid, para 6 Fletcher J.

67 Ibid, para 7 Fletcher J.

Ibid, para 7 Fletcher J.

69 Interestingly, if both sexes had been subject to the same weight restrictions, male employees could have had a claim for disparate impact discrimination. While appearing to hold all employees to the same standard, male employees would be held to a stricter weight limit due to being on average heavier than women.

70 Frank, above n 58, para 10 Fletcher J. 
retaining the approach in Jespersen where men and women are subject to "different but equal" restrictions.

The outcomes of cases using the "unequal burdens" analysis reflect societal attitudes about the role and nature of gender identity. There seems to be a point where normative stereotyping is allowed and expected. ${ }^{71}$ Depending on how the Court views the appearance requirements, the "unequal burdens" test can flout the prohibition on "disparate impact", as discussed in Frank. The difference in outcome is mirrored in the approaches of the Quilter case; that the inquiry stops at difference in treatment or continues to examine the impact of the requirement is directly connected with a finding of discrimination or otherwise.

While Frank does acknowledge subtler forms of discrimination, it still examines discrimination using a comparison between the categories of "men" and "women". Using an "unequal impact" approach may not, then, guard against all types of prejudice. The frame of analysis rests on a binary gender structure. What is lacking is the acknowledgement that sex discrimination does not just occur between men and women, but also among them. In short, these types of judicial responses are tied to the biological sex binary, pitting male requirements against female. This kind of analysis precludes the possibility of analysing whether such normative requirements in themselves are discriminatory. It therefore appears that whichever approach to discrimination is taken in New Zealand, some people will still be denied protection under the law.

\section{TOWARDS FAIRER DISCRIMINATION LAW}

The application of discrimination law has so far been directed at sex discrimination rather than between masculine and feminine genders. Each sex can be categorised into differing genders; for example, popular "labels" for women include "feminine" (heterosexual feminine), "tomboy" (heterosexual masculine), "femme" (homosexual feminine) and "butch" (homosexual masculine). An important judicial development acknowledging this differentiation - and thus intra-gender discrimination - occurred in 1989 with the United States Supreme Court opinion in Price Waterhouse $v$ Hopkins. ${ }^{72}$ In that case Ann Hopkins, a competent female accountant with Price Waterhouse, was denied partnership as she was perceived as being too masculine. Hopkins was advised to "walk more femininely, talk more femininely, dress more femininely, wear make-up, have her hair styled, and wear [jewellery]"73 in order to improve her chances at gaining partnership.

71 Jennifer L Levi "Clothes Don't Make the Man (or Woman), but Gender Might: The Interplay Between Disability and Sexuality" (2006) 15 Colum J Gender \& L 90.

72 Price Waterhouse v Hopkins (1989) 490 US 228.

73 Ibid, 235 Brennan J (Marshall, Blackmun and Stevens JJ concurring). 
The Court held that Hopkins had made out a valid claim of sex discrimination, even though she was not denied partnership due to being female, but rather her failure to conform to sex stereotypes. ${ }^{74}$

The Court also rejected a distinction made by Price Waterhouse between sex and sex stereotyping. The Court found sex stereotyping to be a relevant kind of discrimination and gave an example of why this was so: ${ }^{75}$

An employer who objects to aggressiveness in women but whose positions require this trait places

women in an intolerable and impermissible catch 22: out of a job if they behave aggressively and out of

a job if they do not.

The opinion from Crown Law cited Hopkins as valuable jurisprudence, and emphasised that "unfavourable treatment based on non-conformity to gender stereotypes is sex discrimination."76 The opinion recommended that the courts, by using overseas jurisprudence, could adequately protect gender identity by inferring its inclusion within the ground of "sex". However, this is yet to be affirmed by the New Zealand courts. There is a fork in the discrimination road from Quilter, of which the ultimate direction cannot be confidently predicted.

A clearer statement would be made on this issue if gender was explicitly included as a separate ground. The scope could conceivably expand to also protect "normal" masculine and feminine genders, to demonstrate that all genders are worthy of protection as separate identities to biological sex. An additional clause may be necessary for those who fall outside the sex/gender binary, to communicate clearly to the courts and conservative employers that those who fall within Vade's "gender galaxy" are protected. Such measures are discussed in depth below.

\section{A Improving Legal Processes}

It may be the nature of New Zealand's dispute resolution process that is responsible for slowing the growth of precedent and legal principles in this area. There are at least two ways this can be addressed.

Firstly, there must be some kind of safety net for those claims such as Parore that fall between the jurisdictions of the ERA and HRC. It is not adequate for the forums to decide not to exercise their jurisdiction in this area because another could have heard the claim, particularly as claimants are only allowed one avenue of redress. There must be willingness on the part of the body that the claim falls before to tackle the issues raised in the complaint. If this is not the case there will be no development in the law or in the skills of those hearing the claims in gendered appearance discrimination. The HRC must decide to stand on the side of practical justice rather than

74 Ibid, 251 Brennan J (Marshall, Blackmun and Stevens JJ concurring).

75 Ibid.

76 Crown Law Office, above n 53, para 24. 
consistency, and the ERA must embrace all parts of the claim it hears. If the claim is rejected by one body as being outside its jurisdiction, there needs to be some process for rehearing by a more suitable authority.

Secondly, the bodies must adhere to a set of principles regarding discrimination. Requiring the ERA or HRC to give reasons for decisions will not aid future claimants unless the bodies are required to look to previous case law and legal theory. Yet, if engaged in legal analysis, they are acting in much the same manner as the courts, which may frustrate the purpose of establishing such bodies. We may wind up in a more precarious position than if claims were heard in a traditional forum as members do not have to be legally trained and may thus lack experience in legal analysis. What may be the best result is a compromise between legal analysis, practical justice, and administrative flexibility with low-level authorities alive to the need for protection against gender discrimination, and claimant concerns regarding legal analysis directed up to an appellate hearing. This would eliminate legal inaccuracies and decisions that appear to rest on personal opinion. The creation of guidelines advising decision makers about what "sex" discrimination includes would be valuable. Principles arising from the recent opinion from Crown Law and jurisprudence from the United States are important possible sources of this.

\section{B Incorporation of Developed Jurisprudence}

Cases such as Jespersen demonstrate the power of judicial attitudes in shaping the law. This kind of reaction is masked by legal analysis that pits claimants against a binary set of norms. Not only must claimants prove they were treated unequally as part of a class based on sex; they must fall within this class, signalling judicial refusal to protect those who do not conform to traditional gender divisions. This kind of reasoning must be avoided by New Zealand courts and dispute resolution bodies.

New Zealand has no valuable jurisprudence at lower levels of the justice system in relation to gendered appearance discrimination, and very little guidance from the courts. Quilter appears to have given the courts a choice between a "difference in treatment" and an "unequal impact" approach. However, a third option for gender discrimination that sits outside of these is possible from Hopkins. It is thus advantageous to look to the United States to explore how gender rights in New Zealand can be better affirmed.

As stated above, gender is "social sex" and is the culturally interpreted signal of two pieces of information: that a person is a man or a woman, and what "kind" of man or woman they are. We read these signals using commonly understood signs such as differing clothes and makeup, which become sex stereotypes. To treat someone unfairly because they do not perform the accepted gender display for their body is to engage in sex stereotype discrimination. The Hopkins move to include sex stereotypes as a source of discrimination in themselves offers the capability for protection to those who do not fit within typical gender norms, for example the taboo against cross-dressing 
men. ${ }^{77}$ If sex stereotyping was clearly defined as a prohibited ground of discrimination by the courts, there would be far fewer legal gaps in which discriminatory appearance requirements could exist, meaning fairer employment and formal recognition of gender diversity. ${ }^{78}$

Looking to sex stereotyping allows both inter and intra-gender analyses to be conducted. For discrimination law to defend all gender identities, sex stereotypes must be acknowledged as relevant to discrimination as well as to harassment and must be applied instead of analyses that focuses on binary sex comparisons. Such theory must be included in recommendations to dispute resolution bodies in New Zealand.

\section{Formal Recognition of Gender as a Prohibited Ground}

A statement has been made by the Solicitor-General confirming the inclusion of gender identity within the existing protections of the Human Rights Act. This analysis, as well as the move toward a "sex stereotype" approach by the courts, may preclude the need for a separate ground of "gender" inserted into New Zealand's human rights legislation, as was suggested by Georgina Beyer MP. It would remove the essentiality of a claimant's gender, with a broader understanding of what sex discrimination can include. However this could make the category of "sex" gender-blind. Vade noted: "If we act as if gender does not exist, then we act as if sexism and transphobia do not exist and reinforce the privilege of gender-normal genders, in particular male genders." 79

The opinion by the Crown Law Office, while highly persuasive, is extra-judicial and only a guide for how the courts should interpret the legislation. There is no guarantee that when the courts do come to analyse the issue, they will adopt the approach suggested. What is needed is something stronger: a formal statement of the existence of rights. The inclusion of "gender" as a separate ground in the Human Rights Act would send a strong signal to employers, dispute resolution bodies and conservative judges. Inclusion of "gender" may increase awareness that this kind of discrimination is present and in need of prevention. An alternative route and compromise between implicit inclusion and explicit addition would be to add the words "and sex stereotypes" to the prohibited ground of "sex, which includes pregnancy and childbirth" in section 21(1)(a). This would send a bolder message to employers than a statement by the courts, while not adding an entirely separate ground to the Act.

It is debatable whether formal recognition will result in attitudinal change in society. Rights remain embedded within their social context, and if not exercised have little practical force.

77 For an example where Hopkins reasoning has applied to such facts, see Doe ex rel Doe v Yunits (2000) WL 33162199 (Mass Sup Ct).

78 Carbado, Devon, G Mitu Gulati, and Gowri Ramachandran, "Makeup and Women at Work" 2006 Harv Civ Rts-Civ Lib L Rev 39, 24.

79 Vade, above n 3, 278. 
However, law is a powerful influence on other normative beliefs, and may alter "existing cultural frameworks and practices that help construct social life." ${ }^{80}$ Inclusion also serves to validate gender as a real identity. In a powerful statement in his article, Vade declared "I do not want to rid myself of my gender; I want to reclaim it." 81

\section{CONCLUSIONS}

Gender is a slippery concept, crucially tied to notions of self identity, social acceptance and success. The debate continues as to whether gender is an innate part of an individual or a cultural act which is learned. What is clear, as evidenced by literature and litigation, is that gender is considered an important aspect of personal identity and is worthy of protection. As such, it is critical that it is not a source of permissible discrimination in a central space of modern society, the workplace. Current employment law in New Zealand fails to satisfactorily address gendered appearance discrimination. There are gaps in the law which are a result of the type of system existing or employed to deal with claims and the way this system is used in practice. Steps must be taken to address these issues.

Even though the Solicitor-General has confirmed that gender identity is covered by the Human Rights Act, this does not go far enough to protect the way this is mediated through employment. Explicit inclusion will send a stronger message to employers in their treatment of employees and aid workers in understanding their rights. There are two ways this can be achieved. Gender as a prohibited ground can be fitted within an existing provision, or be added as a separate ground to the Human Rights Act. Formal lawmaking bodies must decide which it is to be. Parliament can move to include "gender" or "sex stereotypes" within the Human Rights Act or the courts can follow the United States' approach and affirm that "sex" includes "sex stereotyping" or "gender".

While this would broaden and elucidate the scope of legislative protections, the application of the law could also be improved. The forums where claims are heard must address the issues rather than eluding responsibility for them. The judicial system needs to recognise and protect diverse identities rather than just those that fall within the comfortable biological binary. These steps can occur with a greater awareness and understanding of human rights regarding sex stereotyping and gender.

Courts addressing matters of employment discrimination in New Zealand have the opportunity to take advantage of the United States jurisprudential journey. A principal error would be to view developments in other jurisdictions as signalling a conclusion to the gender debate. Organisations administering human rights must remain alive to developments in social, political and legal theory

80 Catherine R Albiston "Bargaining in the Shadow of Social Institutions: Competing Discourses and Social Change in Workplace Mobilization of Civil Rights" (2005) 39 Law \& Soc'y Rev 2.

81 Vade, above n 3, 277. 
surrounding gender in order to better implement formal gender equality. While formal equality does not signify the end to all instances of discrimination, it is a valuable tool to shift social attitudes, which may effect greater equality in real terms for New Zealanders. 